\title{
PERANCANGAN SISTEM INFORMASI KINERJA KARYAWAN UNIVERSITAS LANCANG KUNING
}

\author{
Alexsander Yandra, Bayu Febriadi, Zamzami \\ Universitas Lancang Kuning \\ e-mail: Alex@unilak.ac.id
}

\begin{abstract}
Computer-based information is very influential in the world of work, as well as web-based information systems are used as a means of information enhancement. Utilization will facilitate a job as well as data processing faster, the decision will be taken more precisely, saving time and cost. In addition, web-based information systems can also be an efficient means of promotion and information resources that can be accessed by Internet users who are increasingly widespread. In the Faculty of Computer Science, the absence of media as a means of gathering RPKPS while the application of the computer and internet and resources already exist, so difficult in adjusting diktat subjects given lecturers against the competence of the study program and for the development of the competence of the study program
\end{abstract}

Keywords: KinerjaKaryawan, Information System, Online

\begin{abstract}
Abstrak
Sistem informasi berbasis komputer sangat berpengaruh pesat dalam dunia kerja, begitu juga halnya sistem informasi berbasis web dimanfaatkan sebagai sarana peningkatan informasi.Universitas lancang kuning adalah salah satu universitas terbesar yang ada di Propinsi Riau, dalam operasional sehari-hari universitas lancang kuning juga menggunakan karyawan sebagai tenaga kerja untuk pelaksanaan pekerjaan sehari-hari. karyawan yang bekerja di universitas lancang kuning sesuai dengan peraturan tenaga kependidikan universitas lancang kuning, dimana jam kerja di atur mulai dari senin sampai dengan jumat dimulai pukul 08.00 sampai dengan 16.00 wib. Selain jam keja di atas karyawan universitas lancang kuning juga membuat laporan kinerja mereka, tetapi berdasarkan laporan dari ketua badan penjamin mutu universitas lancang kuning pada acara Rapat Kerja yang dilaksanakan di Hotel Mutiara Merdeka Pekanbaru pada tanggal 18 sampai dengan 19 Juli 2017 tidak ada karyawan yang membuat dan menggumpulkan laporan kinerja mereka .Karyawan tidak ada membuat dan menggumpulkan laporan kinerja dikarenakan belum adanya sebuah sistem yang dapa tmembantu mereka dalam membuat laporan kinerja tersebut.
\end{abstract}

Kata Kunci : KinerjaKaryawan, SistemInformasi, Online

\section{PENDAHULUAN}

Sistem informasi berbasis komputer sangat berpengaruh pesat dalam dunia kerja, begitu juga halnya sistem informasi berbasis web dimanfaatkan sebagai sarana peningkatan informasi. Pemanfaatan tersebut akan mempermudah suatu pekerjaan seperti halnya pengolahan data lebih cepat, keputusan yang akan diambil lebih tepat, menghemat waktu dan biaya. Selain itu, sistem informasi yang berbasis web juga dapat menjadi sarana promosi yang efesien dan sumber informasi yang dapat diakses oleh pengguna internet yang semakin lama semakin luas. Karyawan adalah seseorang yang bekerja pada suatu tempat yang memberikan pekerjaan, karyawan merupakan tenaga penggerak dalam beroperasinya suatu perusahaan atau lembaga. Karyawan dalam melakukan pekerjaannya harus mematuhi peraturan dan standar operasional prosedur yang berlaku. 
Universitas lancang kuning adalah salah satu universitas terbesar yang ada di Propinsi Riau, dalam operasional sehari-hari universitas lancang kuning juga menggunakan karyawan sebagai tenaga kerja untuk pelaksanaan pekerjaan sehari-hari. karyawan yang bekerja di universitas lancang kuning sesuai dengan peraturan tenaga kependidikan universita lancang kuning, dimana jam kerja di atur mulai dari senin sampai dengan jumat dimulai pukul 08.00 sampai dengan 16.00 wib. Selain jam keja di atas karyawan universitas lancang kuning juga membuat laporan kinerja mereka, tetapi berdasarkan laporan dari ketua badan penjamin mutu universitas lancang kuning pada acara Rapat Kerja yang dilaksanakan di Hotel Mutiara Merdeka Pekanbaru pada tanggal 18 sampai dengan 19 Juli 2017 tidak ada karyawan yang membuat dan menggumpulkan laporan kinerja mereka. Karyawan tidak ada membuat dan menggumpulkan laporan kinerja dikarenakan belum adanya sebuah sistem yang dapat membantu mereka dalam membuat laporan Kinerja tersebut. Diharapkan dengan adanya perancangan aplikasi system informasi karyawan dapat menghasilkan Bagaimana merancang sebuah sistem informasi laporan kinerja karyawan universitas lancang kuning sebagai sarana dalam membuat laporan kinerja karyawan pada universitas lancang kuning. Serta dengan memanfaatkan aplikasi berbasis online menggunakan database sebagai pengolahan data elektronik sebagai monitoring kinerja pegawai pada badan penjamin mutu universitas lancang kuning.

\section{METODE}

Dalam artikel ini menggunakan metode pengumpulan data dan metode pengembangan sistem sebagai berikut :

\section{Metode Pengembangan Sistem}

Pengembangan sistem dapat berarti menyusun suatu sistem yang baru untuk menggantikan sistem yang lama secara keseluruhan atau memperbaiki sistem yang telah ada. Sedangkan tahapan utama siklus hidup pengembangan sistem terdiri dari : metode pengembangan terstruktur dengan pendekatan siklus hidup pengembangan sistem (System Development Life Cycle atau SDLC). Terdiri dari beberapa fase antara lain sebagai berikut :

a. Perencanaan (Planning)

Pada tahap ini lebih fokus pada penafsiran kebutuhan dan diagnosa masalah dengan mendefinisikan sasaran dantujuan dari sistem yang akan dibangun.

b. Analisa Sistem (System Analysis)

Pada fase ini dilakukan analisa terhadap sistem yang ada dengan metode yang digunakan yaitu metode wawancara dengan pihak-pihak yang terkait dan melakukan pengamatan terhadap kondisi pemda yang menjadi ruang lingkup penelitian. Pada fase ini meliputi: menentukan obyek, mempelajari organisasi, menganalisis kebutuhan output, menganalisis kebutuhan input, evaluasi efektifitas sistem.

c. Perancangan Sistem (System design)

Dalam merancang sistem ini berdasar pada kebutuhan dan masalah yang dihadapi pada obyek penelitian. Pada fase ini meliputi perancangan basis data, perancangan antar muka pengguna, kebutuhan perangkat keras, perancangan jaringan, kebutuhan perangkat lunak.

\section{Alat dan Teknik Pengembangan Sistem}

Metodologi pengembangan sistem terstruktur membutuhkan alat dan teknik. Alat yang digunakan dalam suatu metodologi umumnya berupa gambar atau diagram atau grafik agar lebih mudah dimengerti. Selain berbentuk gambar, alat yang digunakan juga tidak berupa gambar misalnya kamus data, struktur inggris, atau formulir-formulir untuk mencatat atau menyajikan data.

Alat-alat pengembangan sistem yang berbentuk grafik diantaranya : 
a. Diagram HIPO (Hierarchy plus Input-Proces-Output).

b. Diagram aliran data (DFD atau Data Flow diagram).

c. Diagram keterhubungan entitas (ERD atau Entity Relationship Diagram).

Alat yang berbentuk grafik yang umum dapat digunakan pada semua metodologi antara lainbagan alir sistem, bagan alir program, bagan alir proses, bagan organisasi dll

\section{HASIL DAN PEMBAHASAN}

Bagian menjelaskan pembahasan mengenai proses-proses yang ada pada kerangka kerja penelitian sebagai berikut.

\section{Rancangan Sistem yang baru}

Penulis merancang suatu sistem dengan menggunakan metode pengembangan sistem development lyfe cycle (SDLC) dengan alat bantu sistem pendekatan unified modelling language (UML).

\section{Usecase Diagram}

Usecase Diagram menjelaskan gambaran aktor-aktor yang terlibat dalam penggunaan sistem yang akan dibangun, dapat dilihat pada gambar 1. dibawah ini:

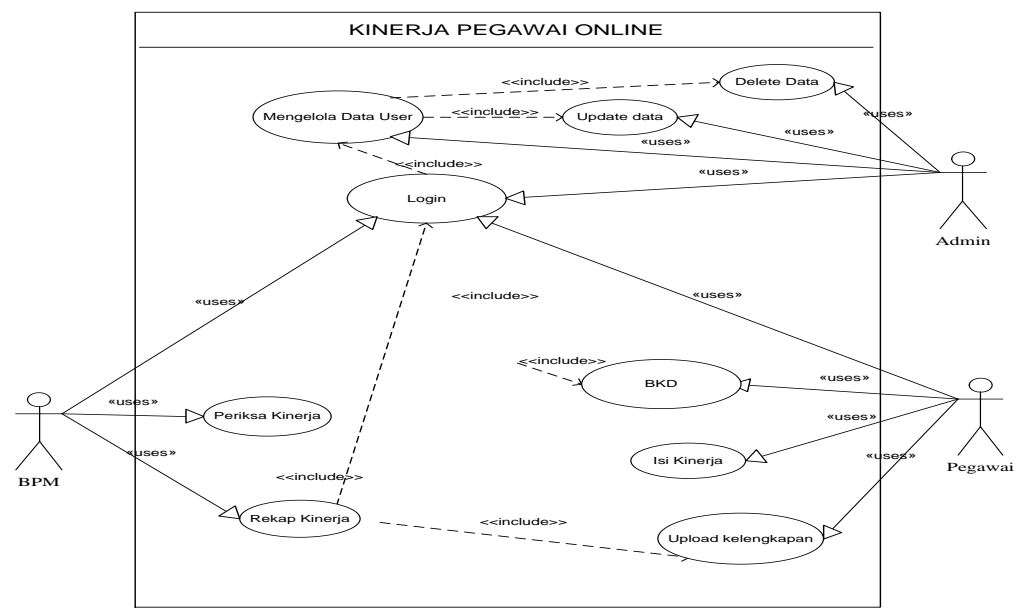

\section{Gambar 1. Usecase Diagram}

Penjelasan:

Dalam perancangan sistem ada 3 aktor yaitu : Admin, Badan Penjamin mutu dan Pegawai. Lalu Admin bertugas mengontrol sistem, mengisi content, mengelola akun pengguna sistem, maintenance aplikasi dalam pengumpulan kinerja. Sehingga Pegawai bertugas sebagai upload kinerja kedalam sistem, mengupload materi file-file pendukung.Badan Penjamin mutu mengontrol apakah kinerja yang di upload pegawai apakah sudah sesuai dengan yang diharapkan.

\section{Activity Diagram}

Activity Diagram menjelaskan bagaimana alur dari sistem yang dikembangkan dalam pengumpulan aplikasi laporan kinerja pegawai berbasis online, dapat dilihat pada gambar dibawah ini: 


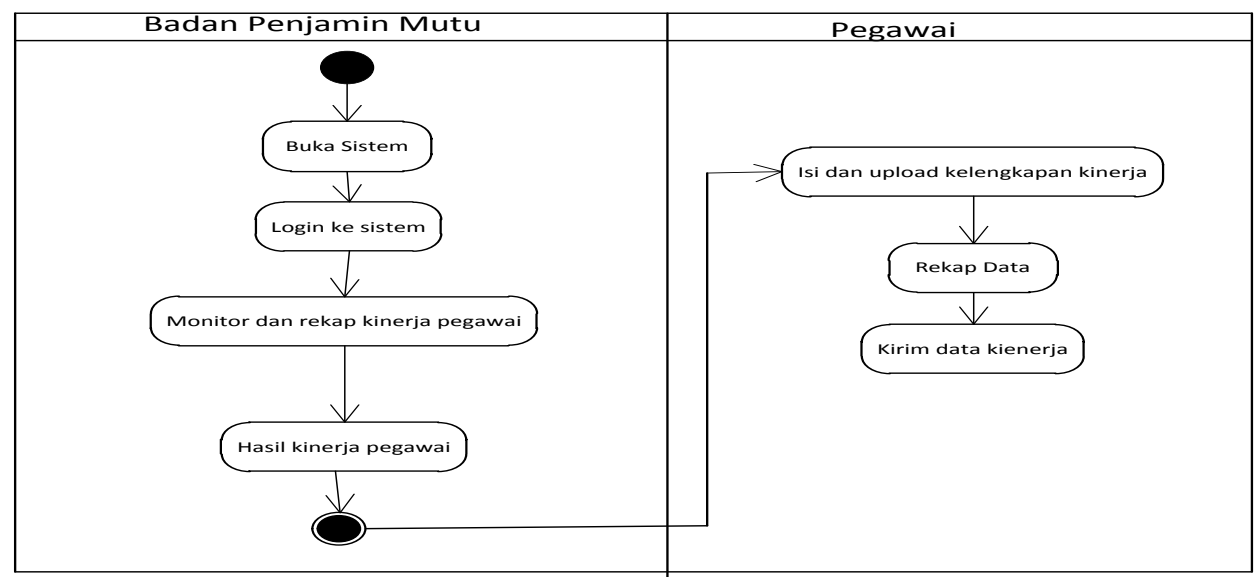

Gambar 2. Activity Diagram

Penjelasan:

Pada activity diagram menjelaskan alur pegawai dalam pengumpulan kinerja terhadap sistem berbasis online.Pegawai juga membaca dan melihat panduan dalam pembuatan format kinerja lalu menyesuaikan dengan panduan yang diberi oleh Badan Penjamin mutu.Badan penjamin mutu mengontrol apakah pegawai sudah mengupload laporan kinerja dan file-file pendukung.Badan penjamin mutu menyesuaikan kinerja yang sudah di upload dan merekap data kinerja apakah sudah sesuai dengan pelayanan yang diharapkan.

\section{Class Diagram}

Class Diagrammenjelaskan entitas dan atribut didalam sistem pengumpulan kinerja pegawai online, dapat dilihat pada gambar di bawah ini :

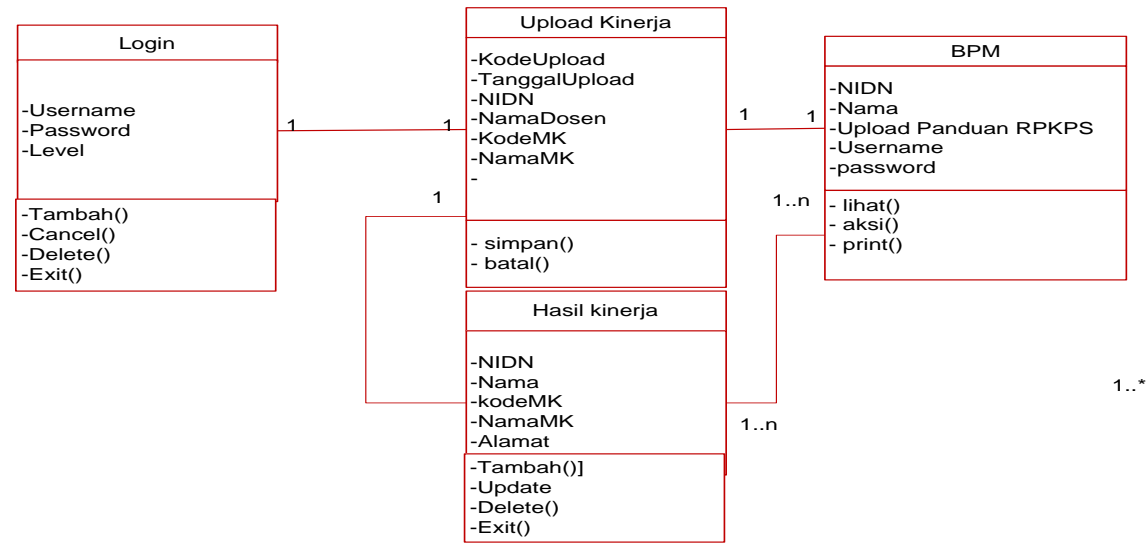

Gambar 3. Class Diagram

Penjelasan:

Pada class diagram ada 4 entitas dalam sistem pengumpulan kinerja online yaitu: Login, upload kinerja, Pegawai, dan Badan Penjamin Mutu.Masing-masing entitas memiliki atribut yang merupakan penjelasan dari entitas tersebut.Pada class diagram juga menjelaskan integritas aliran data dalam sistem yang dikembangkan.

\section{Rancangan Design Aplikasi}

Tampilan Login (Untuk User)

Pada rancangan tampilan menu utama aplikasi Kinerjaa pegawai dapat dilihat pada gambar 5 dibawah ini. 
Pada rancangan tampilan menu utama aplikasi Kinerjaa pegawai dapat dilihat pada gambar 5 dibawah ini.

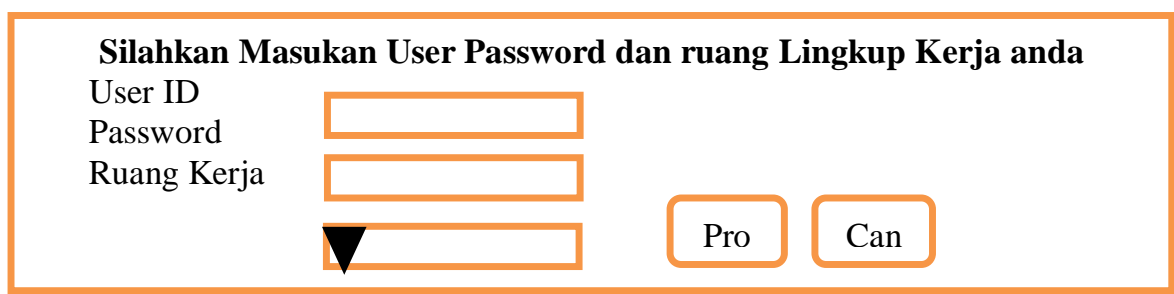

Gambar 5. Design Tampilan Menu Login

Tampilan Utama Setelah Login (Untuk User)

Pada rancangan tampilan menu utama aplikasi Kinerjaa pegawai dapat dilihat pada gambar 6. dibawah ini.

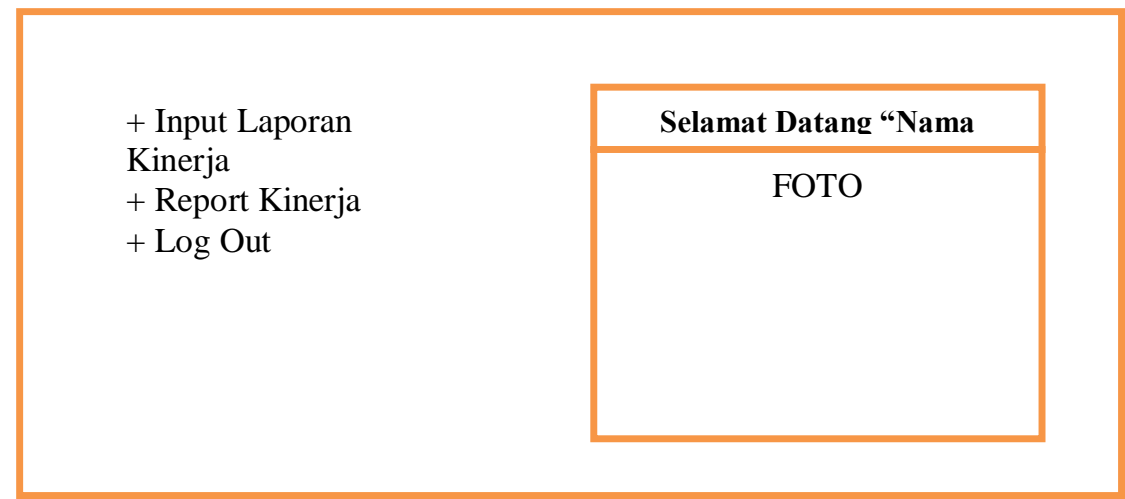

Gambar 6. Design Tampilan Menu Setelah Login

Tabel 1. Data Jenis Kegiatan Karyawan Beban kinerja pegawai

\begin{tabular}{|l|l|l|l|l|l|l|l|}
\hline \multirow{2}{*}{ NO } & \multirow{2}{*}{$\begin{array}{l}\text { Kenis } \\
\text { Kegiatan }\end{array}$} & \multicolumn{3}{|l|}{ Beban Kerja } & \multicolumn{2}{l|}{$\begin{array}{l}\text { Masa } \\
\text { Penugasan }\end{array}$} & \multicolumn{2}{l|}{ Kinerjaa } & Rekomendasi \\
& & $\begin{array}{l}\text { Bukti } \\
\text { Penugasan }\end{array}$ & SKS & & $\begin{array}{l}\text { Bukti } \\
\text { dokumen }\end{array}$ & SKS & \\
\hline 1. & Xxxxxx & Xxxxxx & 99 & xxxxxx & xxxxxx & 99 & Xxxxxx \\
\hline 2. & & & & & & & \\
\hline
\end{tabular}

2 Tabel Data Kegiatan Laporan Kinerja Pegawai

\begin{tabular}{|c|c|c|c|c|c|c|c|}
\hline \multirow[t]{2}{*}{ NO } & \multirow{2}{*}{$\begin{array}{l}\text { Jenis } \\
\text { Kegiatan }\end{array}$} & \multicolumn{2}{|c|}{ Beban Kerja } & \multirow{2}{*}{$\begin{array}{l}\text { Masa } \\
\text { Penugasan }\end{array}$} & \multicolumn{2}{|l|}{ Kinerjaa } & \multirow[t]{2}{*}{ Rekomendasi } \\
\hline & & $\begin{array}{l}\text { Bukti } \\
\text { Penugasan }\end{array}$ & SKS & & $\begin{array}{l}\text { Bukti } \\
\text { dokumen }\end{array}$ & SKS & \\
\hline 1. & Xxxxxx & Xxxxxx & 99 & Xxxxxx & $\mathrm{Xxxxxx}$ & 99 & Xxxxxx \\
\hline 2. & & & & & & & \\
\hline
\end{tabular}

Tampilan Data Pilihan Cetak Aplikasi Beban kinerja Pegawai

Pada rancangan tampilan menu utama aplikasi kinerja pegawai dapat dilihat pada gambar 10 . dibawah ini. 


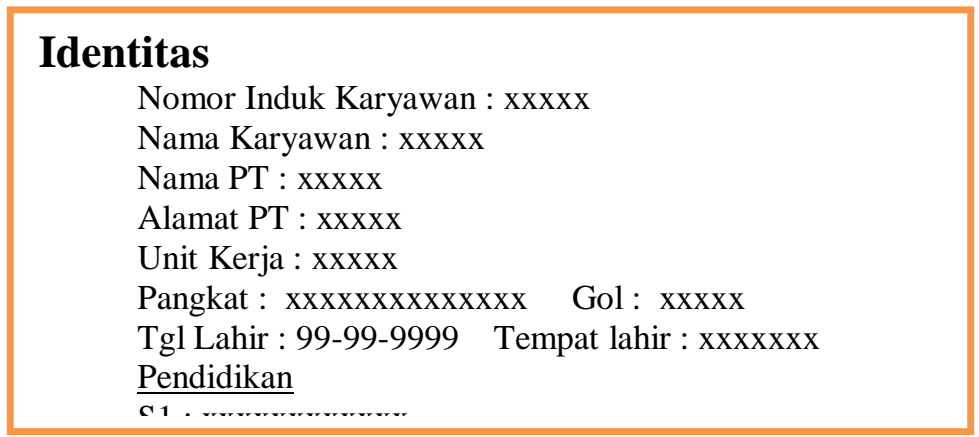

\section{Gambar 10. Design Tampilan DataBKP}

Tampilan Data Data Pengesahan Beban Kinerja pegawai

Pada rancangan tampilan pengesahan beban kinerja pegawai aplikasi kinerja pegawai dapat dilihat pada gambar 11. dibawah ini.

\begin{tabular}{|l|l|l|l|l|}
\hline \multirow{2}{*}{ NO } & \multirow{2}{*}{ Jenis Kegiatan } & \multicolumn{2}{|l|}{ Beban Kerja } & Masa \\
\cline { 3 - 5 } & & $\begin{array}{l}\text { Bukti } \\
\text { Penugasan }\end{array}$ & SKS & Penugasan \\
\hline 1. & Xxxxxx & xxxxxx & 99 & Xxxxxx \\
\hline 2. & & & & \\
\hline
\end{tabular}

Gambar 11. Design Tampilan DataPengesahan BKP

Tapilan Data Cetak Aplikasi Laporan kinerja Pegawai

Pada rancangan tampilan cetak laporan kinerja pegawai aplikasi kinerja pegawai dapat dilihat pada gambar 12 dibawah ini.

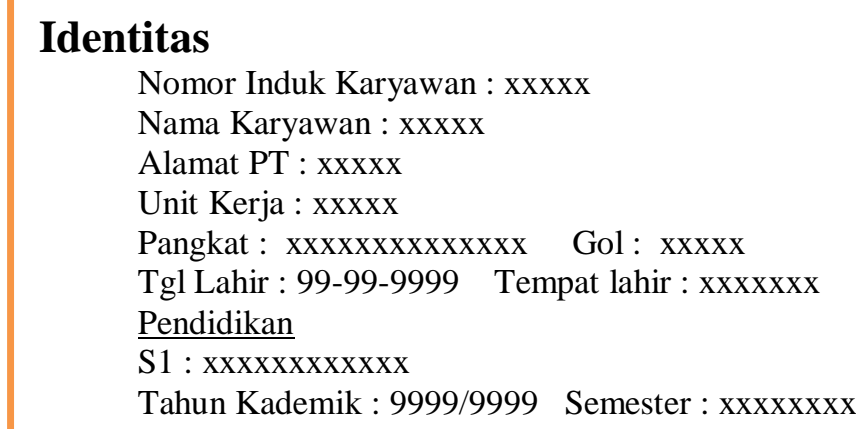

\section{Gambar 12. Design Tampilan Data LKP}

Tampilan Data Data Pengesahan Laporan Kinerja pegawai

Pada rancangan tampilan Laporan kinerja pegawai aplikasi kinerja pegawai dapat dilihat pada gambar 13. dibawah ini.

\begin{tabular}{|l|l|l|l|l|l|l|l|}
\hline NO & \multirow{2}{*}{$\begin{array}{l}\text { Jenis } \\
\text { Kegiatan }\end{array}$} & \multicolumn{3}{|l|}{ Beban Kerja } & Masa & Kinerja & Rekomendasi \\
\cline { 5 - 6 } & & $\begin{array}{l}\text { Bukti } \\
\text { Penugasan }\end{array}$ & SKS & Penugasan & $\begin{array}{l}\text { Bukti } \\
\text { dokumen }\end{array}$ & SKS & \\
\hline 1. & xxxxxx & Xxxxxx & 99 & xxxxxx & xxxxxx & 99 & Xxxxxx \\
\hline 2. & & & & & & & \\
\hline
\end{tabular}

Gambar 13 Design Tampilan DataPengesahan LKP 


\section{KESIMPULAN}

Setelah dilakukan kegiatan perancangan pada universitas lancang kuning, maka penulis dapat menyimpulkan bahwa:

1. Kegiatan penelitian ini menghasilkan sebuah kerangka rancangan aplikasi pegawai untuk membuat laporan kinerja dalam mengukur kinerja pegawai universitas lancang kuning.

2. Kerangka aplikasi penilaian kinerja yang dibangunmenyesuaikan dengan kebutuhan pegawai universitas lancang kuning sehingga dapat digunakan sebagai panduan dalam membangun aplikasi kinerja pegawai berbasis online

\section{DAFTAR PUSTAKA}

[1] I. F. Wendi Wirasta., S.T,.. “JURNAL LPKIA, Vol.1 No.1, OKTOBER 2014 Perancangan Sistem Informasi Penyewaan Alat-Alat Pesta Berbasis Web Di Narda Pesta,” J. LPKIA, vol. 1, no. 1, 2014.

[2] A. Lipursari, "No Title,” J. STIE SEMARANG, vol. 5, no. 1, pp. 26-37, 2013.

[3] M. K. Drs. Hermansyah Sembiring, M.Kom., Nurhayati, S.Kom., "Sistem Informasi Jumlah Angkatan Kerja Menggunakan Visual Basic Pada Badan Pusat Statistik ( Bps ) Kabupaten Langkat," J. KAPUTAMA, vol. 5, no. 2, pp. 13-19, 2012.

[4] Undang Undang Republik Indonesia No.13 Tahun 2003, “Ketenagakerjaan,” no. 1, 2003.

[5] A. F. Batubara, "Perancangan Website Pada Pt . Ratu Enim Palembang," R E I N T E K J. Ilmu Pengetah. Dan Teknol. Terap., vol. 7, no. 1, pp. 15-27, 2012.

[6] E. K. Yeremias Budi Liman Hege1, Uning Lestari2, "Sistem Informasi Geografis (Sig) Pelayanan Kesehatan Di Kotamadya Yogyakarta Berbasis Web,” Script, vol. 1, no. 2, pp. 168-175, 2014.

[7] Anisya, "Aplikasi Sistem Database Rumah Sakit Terpusat Pada Rumah Sakit Umum (Rsu) 'Aisyiyah Padang Dengan Menerapkan Open Source (Php - Mysql)," J. Momentum, vol. 15, no. 2, p. 51, 2013.

[8] A. Wahju and R. Emanuel, “Andi Wahju Rahardjo Emanuel, MSSE,” vol. 7, 2012.

[9] Haviluddin, "Memahami Penggunaan UML ( Unified Modelling Language )," Memahami Pengguna. UML (Unified Model. Lang., vol. 6, no. 1, pp. 1-15, 2011.

[10] F. Alhumaidan, "A Critical Analysis and Treatment of Important UML Diagrams Enhancing Modeling Power," Intell. Inf. Manag., vol. 4, no. 5, p. 231, 2012.

[11] Febriadi B, "Efisiensi Sistem Informasi Berbasis Online Dalam Pengumpulan Rpkps Mata Kuliah Untuk Pengembangan Kompetensi Program Studi", Digital Zone : Jurnal teknologi dan informasi, Volume 8, No 1, 2017.

[12] Yandra A, "E-goverment dengan Memanfaatkan Teknologi Informasi"Jurnal Kajian Politik dan Masalah Pembangunan, ISSN : 1978-063X, Volume 12, No 1, 2016. 